\author{
Tóth Zoltán József
}

\title{
Az Egyesült Államok alkotmányának kartális és történeti jellege
}

\section{Unwritten and Written Features of the Constitution of the United States}

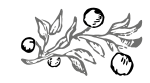

\section{Összefoglalás}

Az alkotmányok között a legkonzervatívabbnak az Egyesült Államok alkotmánya tekinthetố, amely több mint két évszázada tartja fenn a rendet, az igazságot és szabadságot, miközben az egymást követô írott alkotmányok Európában, Ázsiában, Afrikában és Latin-Amerikában a 19. és 20. században egymás után válnak használhatatlanná, illetve az eredetihez képest felismerhetetlen módosításokon esnek keresztül. A korai amerikai alkotmányjogban Edmund Burke nézetei domináltak.

Kulcsszavak: alkotmány, konzervatív, történetiség, konszenzus

\section{Summary}

The most conservative of all constitutions, the Constitution of the United States has upheld order, justice, and freedom for more than two centuries, while the successive written national constitutions of Europe, Asia, Africa and Latin America, drawn up during the 19th and 20th centuries, have collapsed or have been altered out of recognition. Edmund Burke's views came to dominate early American constitutional law.

Keywords: constitution, conservative, historicity, consensus

Dr. Tóth Zoltán József egyetemi docens, Nemzeti Közszolgálati Egyetem, Államtudományi és Közigazgatási Kar (drtoth.z.j@t-online.hu). 
Az Amerikai Egyesült Államok alkotmánytörténete, az ország történetének tükreként és alakítójaként, a múlt örökségével nem terhelt új ember és új világ megalkotásának története a progresszió és a haladás, a fejlődés jegyében. Ez az a küldetés, amit az Egyesült Államoknak be kell töltenie az egész világ történetében. Ez a gondolat utópiaként már Francis Bacon (1561-1621) Nova Atlantis (Új Atlantisz) címú múvében megfogalmazódott, amely egy olyan ország vízióját vetítette előre éppen az elsô északamerikai kolóniák létrejöttekor, amely a múlt által nem terhelt, a gépies, korlátok nélküli technikai és társadalmi fejlődés állama egy távoli földrajzi helyen (Bacon, 1995). A megismerés ebben a világban a gyakorlati tapasztalaton és az egyes megtapasztalt „reáliákból” induktív módon következtet az általánosra. Az új ember, új világ által létrehozott boldogságkor eljövetele a teljesen új megalkotásával és a felvilágosodás forradalmi lendületének szükséges alkalmazásával valósítható meg.

Az Amerikai Egyesült Államok másik tradíciója a hagyomány megốrzése, a kialakított és a hétköznapok családi és közösségi rendjében elért és megélt, alkalmazott jogok, szabadságok megốrzése (conservare = megörzés). Ez a rend az életet átfogó és alakító, közösséget szervezô biblikus, vallásos és hitbeli hagyományok gyakorlati rendje, amely mögött az általános örök isteni törvények és a generációs hagyományok állnak. Az általános isteni-természetjogi törvények igazolják és tükröt mutatnak a hétköznapi gyakorlat igazságainak. A Biblia, a brit jogi és (jog)filozófiai, valamint politikai örökség konzervatív világi rendje és életérzése ez, amely nem kívánja a francia-német felvilágosodásból fakadó eszmék exportálását se magának, se a világ más tájai felé. A boldogság jogát és lehetôségét a hagyomány megôrzése és a forradalmi átalakulással szembeni organikus változások biztosíthatják, ahogy a történelem is igazolja a tökéletes és a tökéletesebb alkotmány megalkotásával is (Kirk, 1990).

Ez a két történeti örökség határozza meg az amerikai alkotmányjogi-jogtörténeti-politikai gondolkodást, amelyet jól szimbolizál az amerikai múvészeti és építészeti hagyomány is: máig egyszerre alkalmazza a brit koloniál és viktoriánus stílust az antik rómaigörög építészeti hagyománnyal, továbbá az olasz reneszánsz építészet stílusát, valamint ezzel egyidejűleg a nemzetközi, majd globális üzleti és politikai világ korlátlan fejlôdését és erôt hirdetô felhốkarcolók és az absztrakt stílus építészetét (Egedy, 2014:231-253).

Az Egyesült Államok alkotmánya (elfogadása: 1787) földünk legrégebbi hatályban lévố, a történeti-íratlan alkotmány jellegzetességeit is magán hordozó, kartális-írott alkotmánya. A másik legrégebbi hatályban lévố alkotmány a történeti-íratlan angol alkotmány, amelynek egyes intézményei, írott és szokásjoga az amerikai alkotmány egyik elôzménye. Miután az Egyesült Államok alkotmánya elfogadása és ratifikálása óta folyamatosan hatályban van, és közjogi intézményei és szabadságjogai (legfeljebb kiterjesztố értelmezésében) alapvetôen nem változtak, az amerikai alkotmányjog ismerete annak történetiségétôl el nem választható (Kirk, 1990:4-17).

\section{A BRIT ÖRÖKSÉG GYÖKEREI}

Az Egyesült Államok alkotmány- és politikatörténetének elsô meghatározó dokumentuma a John Smith vezette „zarándokatyák” által a Mayflower fedélzetén elfogadott 
„Mayflower-szerzôdés” (Mayflower Compact). Ez rögzíti, hogy új gyarmatot alapítanak Virginiában, és meghatározzák az Újvilágban létrehozott közösségük önként vállalt és követett együttélési, politikai szabályait, melyek többek között: a biblikus elvekból levezetett kiválasztottság, a jogegyenlóség, a közjó és a királyi alattvalóként az önkormányzatiság joga az önigazgatás és a törvényhozás területén, valamint a tulajdonjog fontossága, mint a személyi szabadság garanciája. Általánosan elfogadott, hogy ez a dokumentum már magában foglalja az amerikai alkotmányosság egyes meghatározó alapelveit (Egedy, 2016:57-62).

A gyarmatokat megalapító gyarmati szerzódések, a gyarmatok alapítólevelei, alapokmányai is az Egyesült Államok alkotmányának elốzményei. (Rhode Island 1663-as alapítólevele az amerikai függetlenségi háború után is hatályban maradt, ezért ennek az államnak az alkotmánya tekinthetô a legrégebbi tagállami alkotmánynak.) Ezek a „charterek” a 17. századtól a gyarmatokon élő telepesek „elidegeníthetetlen jogait” foglalták magukban, és a gyarmat intézményrendszerére vonatkozó egyes szabályokat. (Az elsố képviseleti gyúlést az amerikai gyarmatokon Virginia 3. chartája, az 1621-es Ordinance and Constitution alapítja meg.) Jellemzốn az egyes gyarmatokon nem hoztak létre állami egyházakat, de minden gyarmatnak volt olyan vallási közössége és egyháza, amely annak a szokásait, közéletét meghatározta. (Ez jellemzô maradt egészen a 20. századig.) A gyarmatokon a 17-18. században kialakult az az alkotmányos szemlélet, hogy a brit jogi hagyomány alapján a személyes jogok napi gyakorlását és a szokásokat a bíróságok védik, a közösségek jogait viszont, amely sokkal inkább amerikai hagyomány, egy egységes szerkezetbe foglalt, a szuverenitással rendelkezô hatalom által elfogadott, illetve jóváhagyott alapokmány, alapítólevél biztosítja.

A gyarmati kor jogrendjére jellemzô, hogy alapvetôen nem lehetett ellentétes a brit jogrenddel, ugyanakkor a gyarmati jogot befolyásolta az egyes kolóniák különbözô vallási háttere, valamint a nem brit eredetú lakosság (holland, francia stb.) szokásait is integrálta, azok autonóm jellegének elismerésével. A vallás, az Istenben való hit, a természetjogi jogértelmezés alapvetô háttere, azaz a jogrend elismerte az Istentôl származó abszolút igazság világkormányzó létezését. A jog, a hatalom és az erkölcs végsố forrása és igazolása a Biblia volt. A protestáns eredetû közösségszervezốdés elvárta az egyén részvételét a közösség formálásában; így a jog is elsôdlegesen az egyének akaratából érvényesül, amit az állam elfogad. A jogrend alakulása alapszabályának tekintették, hogy azok gyújteményes dokumentumokban, szerzôdésekben, chartákban, valamint törvénykönyvekben jelenjenek meg, és legyenek általánosan elfogadottak. Ezek a jogszabálygyújtemények, amelyek a magánosok egymás közötti viszonyát és az állam és a magánosok közötti, elsôsorban mellérendelt jogviszonyokat szabályozták, a szokásjogban már megjelent elveket rögzítették (a Mayflower-szerződés, az elsô gyarmati központban összefoglalt plymouthi törvénykódex 1636-ból, valamint a 1641-es massachusettsi Body of Liberties deklaráció). Ezekben a dokumentumokban a közjóra törekvés, a tulajdon szabadsága, a szabad és egyenlô örökítés szabadsága, a szólásszabadság, a polgári házasság, a nôk jogi alanyiságának az európai gyakorlatnál szélesebb elismerése (például a szabad földtulajdonlás joga és az öröklési jog területén) szerepel (Képes, 2003). 


\section{A FügGeTLENSÉGI NYILATKOZAT}

Az Amerikai Egyesült Államokat a függetlenségi háború alatt megalapító Függetlenségi nyilatkozatot az európai felvilágosodás gondolkodói által átformált természetjogot elismerố filozófia, valamint a társadalmi szerzôdés által megalkotott állami-politikai hatalom szellemi háttere alapján fogalmazták meg (Kirk, 1990:17-35). A természetjogi felfogás szerint az emberek alkotta jog (ún. pozitív vagy tételes jog) felett létezik egy, nem emberek által létrehozott örök jog, és ezért nem vitatható, ugyanakkor az ember alkotta jogot korlátozó, a világ és az ember természetéhez, teremtettségéhez kapcsolódó szabályok ezek, a természetes rend szabályai. A felvilágosodás elốtti természetjogi koncepció ezt összekötötte, a szabad akaratot meg nem kérdôjelezve, az üdvösségre törekvéssel, mivel a személy boldogsága nem korlátozódik a földi létre. Ez a felfogás nem a modern szekularizált politikai szabadságjogok kibontakozásában látta a természetjog, a közjó megvalósulásának feltételét. A korábbi felfogás szerint az egyháznak és az államot vezetốknek elsôdleges felelôsségük biztosítani a természetjog hit és vallás általi, hétköznapi és közéleti érvényesülését, mert különben az ember rosszra hajló természete pusztulásba visz. A felvilágosodás szerint azonban az elidegeníthetetlen emberi jogokat és érvényesülésüket csak az emberek által társadalmi szerzôdéssel létrehozott kormányzat tudja biztosítani. A felvilágosodás természetjogi koncepciója összekapcsolódik a társadalmi szerzôdés jogelméleti, politikai gondolatával. A természetjog felvilágosodáshoz köthetô koncepciója a tételes jog felett álló örök elveket nem a biblikus-szakrális hagyományból, hanem a filozófia Istentôl független vagy éppen azzal szembeni lételméleteiból vezeti le.

A Függetlenségi nyilatkozatban megfogalmazott alapelv, hogy Isten az embereket elidegeníthetetlen jogokban részesítette, amely jogokról lemondani nem lehet, és azok senki által el nem vonhatóak. Ezek az alapvetô jogok „nyilvánvaló igazságok” („self-evident truth”), a természetjog igazságai, „magasabb rendú jogok” („higher law") az ember alkotta pozitív jognál (tételes jognál). Az elidegeníthetetlen jogok tekintetében az emberek egyenlőek: „Minden ember egyenlốként teremtetett... elidegeníthetetlen jogokkal... s ezek közé tartozik a jog az élethez, a szabadsághoz, valamint jog a boldogságra való törekvésre.” Ezek az emberi jogok az Egyesült Államokat vezérló eszmék és erő; jog a bizonyos mértékú anyagi javakra is, fizikai létünk bizonyos szintjének biztosítására, az emberi méltóság tiszteletben tartására és a boldogságra, azaz az élettel való megelégedettségre.

Az emberek, szabad akaratukból, e jogok érvényesülésére hozták létre a törvényes kormányzatot. Amennyiben a kormányzat akadályozza ezeknek a jogoknak az érvényesülését, nem biztosítja, nem védi az emberi jogokat, akkor a népnek joga van a politikai ellentmondásra, oppozícióra, a kormányzat leváltására s új létrehozására. A Függetlenségi nyilatkozat megfogalmazói szerint a brit kormányzat, III. György uralkodása nem más, mint ezen jogok, a telepesek jogainak folytonos megsértése, a „jogtalanságok és önkényeskedések (jogbitorlások) sorozata”. Ezért a népnek joga és kötelessége szembeszállni a zsarnoksággal, felkelni ellene, azaz az anyaországtól történố azonnali és teljes elszakadásra, a függetlenségre, és joga van megalakítani egy, a 
nemzetközi jog szerint is szuverén államot. Ez az állam szabad és független, önállóan visel hadat, szabadon kereskedik, köt szövetséget.

Általánosan elfogadott álláspont, hogy a Függetlenségi nyilatkozat a felvilágosodás eszmerendszeréhez köthető, tükrözi Thomas Jefferson világlátását és Virginia gyarmat, majd állam alaptörvényének szellemiségét (ennek az államnak a szülötte és államférfija Jefferson), amely deklarálja az emberi jogokat, és kiemeli a vallás gyakorlásának jogát és szabadságát. Az Egyesült Államok alkotmánya ezzel szemben sokkal inkább a már megszerzett jogok megôrzésének rendszere, és mindenféle hatalmi önkény elleni, valamint a gyarmati múltból is ismert egyes intézmények gyakorlati átformálása és alkalmazása, hogy az ember rosszra hajló természetét ellensúlyozza a politikai közösségen belül, a kormányzásban. Nem absztrakt filozófiai deklaráció, mint a Függetlenségi nyilatkozat, hanem a politikai gyakorlat tapasztalata. Az Alkotmány megőrzô, konzerváló alaptörvény, a Függetlenségi nyilatkozat pedig a progresszív, az emberi haladás és fejlôdés szellemi alkotásának tekinthetô politikai deklaráció (Kirk, 1990:63-79). A Függetlenségi nyilatkozat deklarálta az új amerikai nemzet születését, de az új állam kormányzati formáját még nem hozta létre.

\section{Az Amerikai Egyesült Államok közJogi elózményei AZ ALKOTMÁNY ELFOGADÁSÁIG}

Az Amerikai Egyesült Államok alkotmányos szemléletének meghatározó elôzménye a Bibliához, a valláshoz, a keresztény hithez köthetô, elsôdlegesen protestáns önkormányzó közösség elve, amely maga alkotja és értelmezi a közösség együttélésének szabályait, és ha szükséges, jog formájában igazságot is szolgáltat. A közösségek (egy hithez és valláshoz tartozó) szabad emberek önkéntes társulásai, amelyek szabadságát, a szabad vallásgyakorlás mellett, az élethez és a boldogsághoz való jog, tulajdon és szabad kereskedés, az angol peres eljárásokból átvett garanciák, a közösség vezetôinek megválasztásának joga alkotják. (Alapvető jog a fegyverviselés joga is, amely életszükséglet volt a vadonban és a „határvidéken” az ôslakos indiánokkal szemben is, az egyre nyugatabbra terjedó letelepedés folyamán. A fegyverviselés és -használat joga a mellérendelt viszonyt is erôsítette az angol-brit katonasággal, majd azzal szemben. A függetlenségi háború gyôzelméhez jelentôsen hozzájárult a szabad fegyveres polgárokból álló milícia. A fegyverviselés a szabadság jelképe azért is, mert Európában a teljes politikai szabadsághoz tartozó fegyverviselés általában a nemesség privilégiuma volt.) Ezek a közösségek elismerik a más vallás- és hitbeli közösségek egyenrangú létezését és politikai, emberi szabadságait is.

A szubszidiaritás gyakorlatban megvalósuló rendszere az önkormányzati szervezódések. Ezt a múködésüket segító, az angol-brit hatalmat is gyakorló gyarmati igazgatási rendszer egészítette ki. A két igazgatási rendszer egymáshoz való viszonya egészen a hétéves háborúig, a kisebb-nagyobb konfrontációkkal együtt, elsôsorban mellérendelt, mint alá-fölé rendelt viszony, alapvetôen egymást kiegészítve, segítve múködtek több mint 170 éven keresztül, Virginia gyarmat alapításától. A létrejött 13 amerikai gyarmat egymással is mellérendelt kapcsolatrendszert alakított ki. A gyarmatok együtt- 
múködése, összefogása kialakulásukkal együtt párhuzamos folyamatként jelentkezett, elôször az angol koronát segítve, majd az azzal szembeni összefogással (például ÚjAnglia Konföderáció 1643-tól, az 1754-es albany kereskedelmi konferencia, majd az 1774-es és az 1775-ös elsố és második kontinentális kongresszus).

A függetlenség kinyilvánítása, az új, 13 gyarmatból álló állam alapvetô múködtetési szükséglete, új közös alkotmányos, igazgatási szervezet kialakítása és annak gyakorlati alkalmazása meghatározó szempont volt, hogy az új államoknak nem egymás rovására túlterjeszkedve, hanem együttmúködve kell saját és közös érdekeiket érvényesíteni, múködésüket biztosítani. Ugyanakkor többségi vélemény volt az is, hogy az államok között kialakítandó új szövetségi rendszer ne az egyes, illetve a szövetséget alkotó államok szabadságát korlátozó, mintegy a brit III. György király és gyarmati igazgatását átvevố államok feletti állam rendszere alakuljon ki, akár demokratikus úton is. 1776 után a nép szuverenitását elsốdlegesen az egyes tagállamokon belül kívánták biztosítani, nem egy, az egyes tagállamokon felett álló új szövetségi rendszeren keresztül megnyilvánulva, egy új szövetségi államot létrehozva. Az akkor két radikális álláspont között kellett a középutat megtalálni, és egy tartós, múködóképes rendszert létrehozni. Az egyik álláspont az volt, hogy a szabadságot kivívó állammá alakuló gyarmatok között csak a 13 független, szuverén állam közötti szövetség jöjjön létre. A másik álláspont szerint, az új államok mondjanak le szuverenitásukról, és hozzanak létre egy új, egységes államot, de mindenképpen egy erôs, új adminisztratív és kormányzati centrumú állam jöjjön létre. A szövetségi állam (amelyben a tagállamok részben vagy egészen feladják önrendelkezésüket az új közös állam javára) vagy csak egy államszövetség létrehozása volt a cél. Az államszövetség elfogadása esetén a szövetségbe lépó államok nem osztják meg a szuverenitásukat az új állammal, hanem csak egy szükséges kormányzati és a legszükségesebb, legminimálisabb adminisztrációt végzố központot hoznak létre, amely feladata nem több, mint a tagállamok közötti egyeztetés, koordináció. A szövetségi államot létrehozni kívánó álláspontot nevezték föderalistának, a laza államszövetséget támogatók pedig az antiföderalisták voltak.

A viták és tárgyalások során jellemzóen már ekkor megjelentek az érdekartikulációk és érdekegyeztetési mechanizmusok összetett és egymás kiegészítô rendszerei, amely az amerikai alkotmányosság általános jellemzójévé vált. Korábbi több évtizedes, már a gyarmati korba is visszanyúló szellemi és politikai érlelódés, viták után kialakult álláspontok alapján, a 2. kontinentális kongresszus kétéves vita után, 1777. november 15-én elfogadta a 13 állam elsố együttmúködését létrehozó alkotmányos rendszerét összefoglaló dokumentumot, a Cikkelyek a Konföderációról és az Örökös Unióról (Articles of Confederation and Perpetual Union), rövidítve a Konföderációs Cikkelyeket (Képes, 2003).

\section{A Konföderációs GiKkelyek}

A Konföderációs Cikkelyek egy államszövetséget hoztak létre a 13 új állam között. Közjogilag létrehozták az Uniót az Egyesült Államokat alkotó független államok között. Az államszövetség nem rendelkezett önálló szuverenitással, azt a szövetségi államok fenntartották maguknak. A kongresszus küldöttei elsődlegesen saját államuk új sza- 
badságát védték, rögzítve azok önállóságát mindenfajta hatalmi önkénnyel szemben is, nyilvánuljon meg az akár egy új szövetségi központ részérôl.

A cikkelyek alapján az Amerikai Egyesült Államok szuverén államok társulása, amelyek vállalták, hogy kölcsönösen támogatják és megvédelmezik egymást, és együttmúködnek a közjó és a közös szabadság érdekében. Az államok között létrehozott unió örökös (perpetual unio), melyben a tagállamok érvényesnek fogadják el a többi állam jogi aktusait. A tagállamok elfogadták azt az elvet, hogy a nem kifejezetten a központi államra ruházott hatáskörök (expressed power) a tagállamoknál maradnak. Késóbb ez az elv az Egyesült Államok alkotmányának egyik alapja lett, de ez ekkor még csak a korlátozott közös védelem egyeztetéses rendszerét és kincstár létrehozását jelentette.

\section{Az Amerikai Egyesült Államok Algotmányának LÉTREHOZÁSA ÉS ELFOGADÁSA}

A konföderációs alkotmányos rendszer egyre nagyobb múködési tehetetlensége a függetlenségi háború megnyerése után drámai módon ütközött ki. A központi végrehajtó hatalommal és szövetségi szintú jogszabályalkotó hatalommal nem rendelkezô Unió nem tudta kezelni az összes tagállamot külön és együtt is sújtó, háború utáni gazdasági válság következményeit, a saját pénzt rontó inflációt, a háborús állami adósságköveteléseket, valamint a külpolitikailag és katonailag továbbra is fenyegetést jelentô NagyBritanniát, a határterületeken az indiánokkal kiújuló konfliktust, a tagállamok közötti feszültségeket, valamint a tagállamokon belül jelentkezô, belsố felkeléshez (mint a Daniel Shays vezette massachusettsi farmerek felkelése 1786-1787-ben) is vezetô válságos helyzeteket. Az államokat és az Uniót irányítók kénytelen voltak szembesülni azzal, hogy amit a háborúban megnyertek, elveszíthetik a békében, az épp megszületố állam politikailag, gazdaságilag, jogilag is széteshet.

A drámai események egy időben történô jelentkezése rákényszerítette az államokat a szorosabb együttmúködésre, amelynek kereteit, elveit egy új alkotmányos berendezkedés volt képes lehetôvé tenni. Az alkotmányozás folyamata évtizedes gyakorlati (jogászi, gazdálkodói, közéleti, katonai) tapasztalatokkal és ugyanakkor széles elméleti, alkotmányjogi tudással rendelkezô államférfiak vezetése, irányítása alatt zajlott. Gondolkodásukat, világlátásukat ókori szerzók, John Locke, Montesquieu, Edmund Burke, az angol jogot értelmezó összefoglaló munka (William Blackstone), Adam Smith és mások munkássága befolyásolta. Különösen meghatározó Edmund Burke munkássága, amely a brit történeti alkotmány szokásjogi gondolkodását és az elsôdleges szokásjogi intézmény formálásának hagyományát hangsúlyozza az államhatalom centralista, mindig kisebbségi érdekeket erôsítő agressziójával szemben. A személyes szabadság garanciái a személyek önszervezôdése és gazdasági autonómiája, valamint az állammal és mások önkényével szemben megvédő bírói ítélkezés. A jó hagyományok gyökerei ugyanakkor biblikusak, amely elvek közösségformáló erejétôl függ a személyi szabadság valósága (Kirk, 1990:80-98; Ostrom, 1994:29-69). Burke kiemeli, hogy a jó alkotmány nem hatalmi önkényt leplező filozófiai absztrakciók kartális alkotmányos átültetése az alkotmányjogba, hanem történeti jellegú. Ugyanis a tör- 
téneti alkotmány mögött az önkormányzó közösség áll, a kartális alkotmány mögött egy kisebbség, amely absztrakt elvekre hivatkozva törekszik akaratát rákényszeríteni a többségre (Ostrom, 1994:29-52; Kirk, 1990:35-48, 63-79). A történeti alkotmányos gondolkodás konszenzusra hajló, türelmesebb, realista. A kartális alkotmány mindig egy éppen fennálló többségre hivatkozó kizárólagos érdekérvényesítés. A filozófusok által kreált absztrakt elvek, melyek garanciája nem az isteni természetjog, hanem a filozófusok szükségszerúen le- és kicserélhetố bölcsessége, amely mindig univerzális, néptôl és hagyománytól függetlenül alkalmazható. Ez globális univerzalizmushoz és uniformizáltsághoz vezet, amelyet a forradalmárok és háborúik valósítanak meg, hatalmukat pedig uniformizált kartális alkotmányok tartósítják. Még Locke nézeteiben is az észjogi természetjog szemlélete tükrözódik. Burke szerint és a brit örökség alapján, a jó alkotmány tekintélyes idó elmúltával a nemzeti tapasztalatokból alakul ki. A vallás a polgári és társadalmi rend alapja, az alkotmányos rend bázisa és feltétele, vagyis a cselekvés végsố mércéje az a felelôsség, amely alapján tetteinkkel felelünk a Mindenhatónak (és nem valamely izmust képviselố államhatalomnak). A szabadság és rend közötti egyensúlyt, amely az elôzoó feltevéseken alapul, a mindenkori természetes arisztokrácia tartja fenn. A természetes arisztokrácia a szellemi és gyakorlati erényt hordozók a közösségben, amely egyensúlyban tartja egyesek korlátlan hatalmi-vagyoni akarását a magánéletben, és az ezt közvetítố, burjánzó és egyre abszolútabb állami hatalommal szemben (Ostrom, 1994:29-52; Kirk, 1990:35-48, 63-79).

A szövetségi állam koncepcióját tehát a föderalisták képviselték, az inkább az államszövetség megerôsítését pártolók voltak az antiföderalisták. A föderalisták közül kiemelkedik John Adams, Alexander Hamilton, George Washington, Edmund Randolph, Gouverneur Morris. A szintén föderalista James Madison és Benjamin Franklin közvetítették az álláspontokat azok között, akik a szövetségi államnak a tagállamok által teljesen átadott szuverenitás és végrehajtói hatalom koncepcióját, valamint a szövetségi állam és a tagállamok közötti kompromisszumos egyensúly államberendezkedési koncepcióját vallották, illetve akik az emberjogi deklaráció elsôdleges alkotmányos szabályozását kívánták, de a föderalista koncepciót nem vagy nem teljesen elvetették (Thomas Jefferson). Az antiföderalisták egyik vezetôje Richard Henry Lee volt.

A föderalisták álláspontját, Alexander Hamilton, James Madison és John Jay folyamatosan közölt írásait a The Federalist Papers címú gyújteményes kötetben foglalták öszsze, az antiföderalista koncepciót képviselók tanulmányait a The Anti-Federalist Papers kötetben publikálták.

A tervezetek tárgyalásával és a három kompromisszum elfogadásával a konvenció túllépett a Konföderációs Cikkelyek megvitatásán, és a philadelphiai konvenció átalakult a „tökéletesebb uniót” megalkotó alkotmányozó konvencióvá (Constitutional Convention at Philadelphia).

A kompromisszumok elfogadása után az alkotmány szövegezése következett, és végül az alkotmány elfogadása. (Az alkotmány végsố megszövegezése Franklin, Hamilton és Madison mellett elsôdlegesen Gouverneur Morris érdeme.) Az Amerikai Egyesült Államok Alkotmányát 1787. szeptember 17-én írta alá és fogadta el 12 állam 39 küldöttje. Óket nevezik „alapító atyáknak” (Founding Fathers). 


\section{Az ALKOTMÁny JELLEMZÉSE}

Az Amerikai Egyesült Államok Alkotmánya máig is hatályos alkotmány, ezért bemutatásakor az alkotmánytörténeti és az alkotmányjogi leírás nem elválasztható. Az alkotmány alapvetốen kartális, írott alkotmány, amely rendelkezik a kartális alkotmány jellegzetességeivel: a tárgykör legfontosabb szabályait egységes jogszabályba foglalja; az egész jogrendszer alapja; elfogadásának, módosításának törvényhozási eljárási feltételei eltérnek a törvények általános elfogadásának, módosításának feltételeitôl; elfogadásához és módosításához csak erre hivatott alkotmányozó gyúlés a feltétel.

Ugyanakkor az Egyesült Államok alkotmánya a történeti alkotmány jellegzetességeit is magán viseli: már múködô intézményekre, hatályos jogokra alapoz; az alkotmány chartája nem egy lezárt alkotmányjogi dokumentum, hanem kiegészítésekkel (amendments) folytatható; a common law, a bírói esetjog alkotmányos jogforrás is; az alkotmányos szokások, konvenciók is az alkotmányos gyakorlat részei; a szövetségi tagállamok alkotmányai szintén az alkotmányos rend részei; alkotmányt módosítani, elfogadni nem csak erre hivatott alkotmányozó gyúléssel lehetséges.

Ezért az amerikai alkotmányjog és -történet sokkal inkább vegyes jellegú és „élô” alkotmányként írja le az Egyesült Államok alkotmányát, elválasztva azt a francia-német felvilágosodás kartálisalkotmány-szemléletétôl, amely az írott alkotmányt elválasztja az addigi történeti múlttól, hagyományoktól, valamint absztrakt jogszemlélete a bármely államban alkalmazható absztrakt elveket helyezi a szabályozás elôterébe (vagy teszi azt kizárólagossá), az adott ország múltjának, jellegzetességeinek, hagyományának rovására.

\section{AZ ALKOTMÁNy SZERKEZETE}

Az Egyesült Államok alkotmánya tömör szövegezésú, két fố részbôl áll: a „Document”ből és az „Amendment(s) ”-ekből, azaz a kiegészítés(ek)bôl. A „Document” soha nem változtatható meg (csak egy teljesen új alkotmány esetleges elfogadásával). Ez két részbôl áll: a preambulumból (Preamble) és 7 cikkelyból (Articles), azaz a fôrészbő́l (Main Body, törzsszöveg). A preambulum az Egyesült Államok kormányzásának, a hatalomgyakorlás, az alkotmányozás (filozófiai) alapvetéseit összegzi, a fôrész 7 cikkelye a hatalomgyakorlás szervezeti rendszeréról rendelkezik. Ezért nem lehet megváltoztatni az alkotmánynak e két részét. A preambulumot és a fơrészt a kiegészítés(ek) (Amendments) bővítik ki, amelyek az alkotmány részeként annak elfogadása és hatálybalépése óta alkotmányos szintû́ jogi, államszervezeti kérdéseket szabályoz. A kiegészítések teszik lehetôvé, teszik képessé, hogy a kormányzás megfelelôen alkalmazkodjon a változó történelmi kihívásokhoz. Ezért is nevezhetố az alkotmány éló alkotmánynak (living document). Az elsố tíz kiegészítést, az emberi jogok gyújteményét (Bill of Rights) 1791-ben fogadták el. (Jelenleg az Egyesült Államok alkotmányának 27 kiegészítése van, a legutolsót 1992-ben fogadták el.) Az Amerikai Egyesült Államok politikai, jogi történetében az alkotmány fontossága szinte „szakrális” jelentôséggel bír az amerikai öntudat formálásában, annak meghatározó elemét jelentve. 


\section{Az ALKOTMÁNy LEgFONTOSABB ALAPELVEI}

Az „alapító atyák” (Founding Fathers) a változó történelmi helyzetekhez alkalmazható, életszerú és átlátható, jól szerkesztett dokumentumot kívántak létrehozni. Az alkotmánynak biztosítania kell, hogy mindenki helyi (local), állami (state) és szövetségi (national) szinten érvényesíthesse az akaratát. Egy ezt biztosító rendszert kívántak az alkotmányban lefektetni úgy, hogy a legfóbb elv, a népszuverenitás elve minden, a világban történó változás ellenére az országban biztosítva maradjon.

A népszuverenitás elsődlegesen az önkormányzatiság elvén keresztül valósulhat meg (Kirk, 1990; Ostrom, 1994; Egedy, 2014; 2016). Mindenkinek joga van saját közösségéhez tartozni, és a közösség tagjaként annak szabályait megalkotni, a közösség életében részt venni, azt alakítani. Valójában ezért az önkormányzatiság (municipalizmus) az alkotmány elsố alapelve. Alapvetố a szövetségi állam és a tagállamok közötti hatalom, a hatáskörök megosztása (a hatalom területi-vertikális megosztása). Az alkotmány rögzíti a kizárólagos szövetségi hatásköröket (exclusive federal powers), a szövetségi és tagállamok közösen megvalósítandó feladatait (concurrent powers), valamint a tilalmazott hatásköröket (denied powers), amit se a szövetségi hatalom, se a tagállamok nem szabályozhatnak. Így nem adhatnak nemességet, tilos a visszaható hatályú büntetố törvénykezés és joggyakorlat, valamint 1863-ig, a rabszolgaság eltörléséig szövetségi szinten a rabszolgaság megszüntetése is. Az önkormányzatiság elvének szövetségi szintre emelése konföderációs gondolat. Az önkormányzatiság és a központi, szövetségi hatalom közötti arányos, a szubszidiaritás elvére (szövetségi hatalom csak odáig terjeszkedhet, amíg a tagállam el tud járni, tovább nem, minden kérdést azon a döntési és igazgatási szinten kell megoldani, ahol a leghatékonyabb és legjobb) épüló megosztás alkotmányos elve a föderalizmus. (A tagállami kormányzat saját földrajzi területeinek határáig hatásköreik teljességével rendelkezik.)

Az alkotmány a legföbb törvény, a jogrend alapja, alaptörvény (supreme law), azaz nem lehet olyan más törvény, ami ellentmondhat az alkotmánynak és alapelveinek, és nincs személy vagy kormányzat, amely hatásköre alól kivonható. Az alkotmány alapszövege megváltozhatatlan, módosítani nem lehet, csak kiegészíteni. Az amerikai közjogi gondolkodás alapelve az alkotmány kicserélhetetlen és kikerülhetetlen tekintélye. Ezért az alkotmányt különleges tisztelet övezi az Egyesült Államokban (amely hasonlítható a magyar Szent Korona korábbi közjogi szerepéhez köthetô tisztelethez). Ezen elvek együttesen formálják (a meghatározott alkotmányos elvek érvényesülésétôl függô) az alkotmányosság amerikai értelmezését.

Az alkotmány biztosítja minden személynek, aki az Egyesült Államokban él, legyen az állampolgár vagy nem állampolgár, a szabadságot és az (emberi) jogokat. Ezt az elvet fokozatosan terjesztették ki a politikai szabadságjogokra. Ugyanis az amerikai demokráciát elsôdlegesen az alkotmányos és közéletben való részvétel jogaként értelmezték, nem a politikai egyenlôség elveként. A részvétel és jogosítottak köre kiterjesztésének elvét Andrew Jackson elnök (1829-1837) mandátuma alatt kezdték alkotmányos értelmezésként és a gyakorlatban bevezetni, folytatva a rabszolgák felszabadításával, majd a szegregáció felszámolásával az 1860-as évektôl az 1960-as évekig, és a nôi választójog 
elfogadásával 1920-ban, majd egyes kisebbségek privilegizálásával (pozitív diszkrimináció). A jogok kiterjesztésében meghatározó szerepet töltött és tölt be az Egyesült Államok Szövetségi Legfelsôbb Bíróságának alkotmányértelmezése.

A Szövetségi Legfelsôbb Bíróság főbírájának meghatározó hatásköre van a bíróság alkotmányszemléletének kialakításában. A Legfelsóbb Bíróság ítéletei meghatározzák a többi szövetségi bíróság ítélkezését és a bíróságok jogértelmezési határait az alkotmányban (az alkotmánykiegészítésekkel) foglaltak értelmezésével. Így a Legfelsôbb Bíróság ítéleteivel képes az egész Unió alkotmányos életét, uralkodó jogpolitikai szemléletét és jogalkalmazási gyakorlatát meghatározni. Az Unió elsô fóbírájának a föderalista John Jay-t nevezték ki (1789-1795). Az 1801 és 1835 között fóbíróként dolgozó, szintén föderalista John Marshall vezette Legfelsőbb Bíróság máig karakterisztikusan meghatározta a bíróság hatásköreit. Az alkotmány III. cikkelye szerint a Legfelsóbb Bíróság hatásköre kiterjed az Egyesült Államok minden olyan jogi és méltányossági ügyére (equity), amelyre az alkotmány, a szövetségi törvények és a nemzetközi szerzôdések vonatkoznak. Alapvetôen ezekben az ügyekben, bármely bírósági fórumon is folyik a per, lehetett a Legfelsóbb Bírósághoz fellebbezni. Ez az eredetileg csak öt bíróból és egy fóbíróból álló testületre hatalmas terhelést jelentett. Az 1891-es bírósági reform (Evarts-törvény) hozta létre a szövetségi fellebbviteli bíróságokat (Fellebbviteli Kerületi Bíróságok), és ekkortól a jogerôs ítéletet ez a bírósági fórum mondta ki, kivéve, ha a fellebbezés alkotmányos jog megsértésére vonatkozik. 1925 óta a Legfelsôbb Bíróság többé nem common law bíróság, az általa hatáskörbe vont eseti ügyekben jogelvi, általános jogértelmezési, valamint az alkotmány értelmezését meghatározó ítéleteket hoznak.

Az alkotmányos normakontroll, azaz a bírói felülvizsgálat (judicial review), az alkotmányosság és törvényesség vizsgálata a Legfelsóbb Bíróság legsajátosabb jogköre. A bíróság ebben a jogkörében egyes szövetségi és tagállami törvények alkotmányellenességét vizsgálja konkrét, egyedi ügyekben, ezekhez a perekhez kapcsolódó konkrét alkotmányos jogsértések esetén. Ez a jogköre alapvetôen az alkotmány VI. cikkelyéból vezethetố le, amely kimondja, hogy az amerikai jogforrási hierarchia csúcsán az alkotmány van, azaz minden más szövetségi és tagállami jogszabály fölött áll. Ez az alkotmánybírósági gyakorlat az elsô ilyen bírósági jogkör az egyetemes alkotmány- és jogtörténetben, amit az esetjogi bíráskodás precedensjoga (common law) alapján alakítottak ki. (Elôzménye a gyarmati idôszakban a londoni Privy Council hatásköre, amely megsemmisíthette az egyes gyarmatok törvényhozó testületeinek rendelkezéseit, amennyiben a brit joggal ellentétesnek ítélte.) Az Amerikai Legfelsôbb Bíróság alkotmánybírósági jogköre nem ismeri az absztrakt elôzetes vagy utólagos normakontrollt, azaz a törvény konkrét peres eseten kívüli alkotmányos felülvizsgálatát annak elfogadása elôtt vagy után (Tóth, 2017).

A polgárháború elôtt és után is, egészen az elsô világháborút követô idôszakig, a Szövetségi Legfelsôbb Bíróság értelmezésében a szabadságjogokat szövetségi törvény és bíróság nem értelmezhette a tagállami törvények ellenében, szúkítve a tagállamok autonómiáját. Ezért a rabszolgaság szövetségi szintû eltörlése 1863-ban és a polgárháborúnak az északi unionisták általi megnyerése a déli konföderációval szemben önma- 
gában nem eredményezte az állampolgári jogegyenlóséget. 1866-ban a Kongresszus elfogadta az elsố polgárjogi törvényt az állampolgári jogok kiterjesztésérôl (Civil Right Act). A törvény alapján valamennyi, az Egyesült Államok területén született polgárt megilleti az állampolgárság az állampolgári jogokkal együtt. Így a törvény eloótti egyenlôség és egyenlố jogvédelem a volt rabszolgákat is megilleti, és a büntetô- és polgári eljáráshoz kapcsolódó jogok, így a perindítás, jogorvoslat, a tanúskodás és a bizonyításhoz való jog is, továbbá a tulajdonhoz kapcsolódó jogok: a tulajdonosi és birtoklási jogok, a kötelmi, az öröklési, a családjogok. A jogok érvényesítéséhez ugyanakkor meg kellett változtatni a Szövetségi Legfelsôbb Bíróság alkotmányértelmezési gyakorlatát, amely a tagállamok jogalkotó és jogértelmezó autonómiáját erôsebb jognak tartotta, mint a szabadságjogok nevében történô szövetségi bírósági beavatkozást és az erre alapozó szövetségi kormányzati intézkedéseket a tagállam ellen (Semonche, 2000:101-169).

Az 1868-ban elfogadott XIV. Alkotmánykiegészítés értelmében a tagállami törvények nem korlátozhatták az alkotmányban és az alkotmánykiegészítésekben szabályozott jogokat. Az alkotmánykiegészítés megállapítja, hogy az állampolgárok egyszerre állampolgárai az Egyesült Államoknak és tagállamuknak. Ezért egyetlen tagállam se fogadhat el olyan törvényt, amely „csorbítja az Egyesült Államok polgárainak jogait (kiváltságait) és mentességeit". Minden állampolgárt minden államban megillet az egyenló jogvédelem, a megfelelố törvényes eljárás. Az alkotmánykiegészítés az „egyenlô jogi védelem” elve mellett bevezette a ,jogszerú eljárás” (a due process) elvét. Ennek értelmében az állampolgárok élethez, szabadsághoz és tulajdonhoz való joga nem korlátozható, csak jogszerú, törvényes eljárással, az alkotmánnyal és az alkotmánykiegészítéssel összhangban lévô törvényekkel. Az ezzel ellentétes szövetségi és tagállami törvény esetén a Szövetségi Legfelsôbb Bíróság élhet az alkotmányos kontrollal, és hatályon kívül helyezheti a szövetségi és a tagállami törvényt is (Semonche, 2000:101-169).

Hiába vált azonban hatályossá a XIV. Alkotmánykiegészítés, és hiába fogadta el a Kongresszus az 1866-os polgárjogi törvény kiegészítéseként az 1875-ös újabb polgárjogi törvényt (diszkrimináció tilalma a színházakban, a közlekedési eszközökön, a vendéglátóhelyeken stb.), amely a szövetségi kormányt felhatalmazza, hogy az egyenló bánásmód elvének gyakorlati alkalmazása érdekében törvényeket alkosson, és igazgatási jogkörében eljárjon. A szövetségi bírósági ítélkezési gyakorlat nem engedte a szabadságjogok érdekében a tagállami autonómia szúkítését jelentô kongresszusi törvények alkalmazását és a szövetségi kormány hatáskörének növelését. A Szövetségi Legfelsóbb Bíróság korlátozott mértékben alkalmazta az alkotmánykiegészítést, csak a magántulajdon védelmében lépett fel a szövetségi vagy tagállami törvényekkel szemben. A tagállami szegregációs, diszkriminációs törvényekkel szemben a XIV. Alkotmánykiegészítést a szövetségi bíróság csak az elsố világháború után kezdte alkalmazni.

Csak fokozatosan, mintegy száz év alatt, a 20. század közepére alakult át a Szövetségi Legfelsốbb Bíróság gyakorlata, kibôvítve és általánossá téve a szabadságjogokat, megfordítva a jogértelmezést, és a szövetségi kormányzatnak, a Kongresszusnak lehetôvé tette a beavatkozást a szabadságjogok védelmére hivatkozva, a tagállamok által követett jogrend megváltoztatásáért a tagállami autonómia korlátozásával. 
Az 1920-1930-as évektôl kialakult a Legfelsôbb Bíróság két irányzata: egyrészt az aktivista irányzat, amely a bíróságot bevonta a napi politikai küzdelmekbe (liberális álláspont), másrészt a passzivista irányzat (a konzervatív álláspont), amely a bíróság tevékenységét a jogon belüli kiegyensúlyozó és a természetjogi szempontokat figyelembe vevó feladatnak értelmezi, hangsúlyozva, hogy nem a bíróság, hanem a népképviseleti szervek feladata minden korban a társadalmi problémákra választ adni. Ugyanis a bíróság nem vonható felelősségre, ellentétben a nép által megválasztottakkal. Az 1950-es évektôl a Legfelsôbb Bíróság aktivista (fôleg Earl Warren bírósága 1953 és 1969 között, és Warren Burger fôbíró elnöksége idején 1969 és 1986 között) alkotmányértelmezô gyakorlata már nemcsak a szövetségi kormányzat hatáskörét tágította ki, hanem eltért a szabadságjogok korábbi természetjogi, hagyományos értelmezésétôl, és bevezette a szabadságjogok (emberi jogok) szekularizációs, a korábbi biblikustól eltérô értelmezését. A világnézeti egyenlőség elvét alkotmányos egyenlőség alapelvként értelmezve, teret adott a kisebbségi jogértelmezések uralkodóvá tételének, ezt tekintve az alkotmányos közmegegyezés feltételének 20. században (Semonche, 2000:169-307; Kirk, 1990:143-157, 201-230).

\section{Ös S ZEGZÉS}

Az amerikai alkotmány megalkotói a történeti kihívásokra mindig megfelelni képes, az egyközpontú hatalomkoncentráció kialakulását kizáró, a jogokat biztosító és a kötelességeket az állampolgár és az állam által betartó jogállami alkotmányos berendezkedést kívántak létrehozni. Vallották, hogy jó alkotmány tekintélyes idôvel alakul ki, ezért a bevált intézményeket, szokásokat meg kell órizni, minden nép alkotmányát saját küzdelmei, gyakorlata, tapasztalatai alakíthatják ki, amely biztosíthatja a stabilitását. Az amerikai alkotmány szerkezete ezért nem követi a merev európai kartális alkotmányok szerkezetét, mert nem lezárt dokumentum, hanem kiegészíthetô, továbbá az alkotmány és alkotmányjog része a tagállamok joga és az angolszász precedensjog is. Nem elvont elvek, hanem inkább a valósággal szembesülés alakítja az alkotmányt, ennek feltétele a közmegegyezés, így válhat az állam „mindenki ügyévé”. A stabilitás alapja, fogalmazták meg, a társadalmi rend stabilitása, amely elválaszthatatlan a cselekvés végsố mércéjétôl, attól a felelősségtől, amely alapján tetteinkkel felelünk a Mindenhatónak. Az alkotmányosság alapja a „természetes arisztokrácia”, a demokrácia nélkülözhetetlen intézménye, akik nem önös érdekeiket képviselik, hanem az egész nemzetet integrálják, a középosztály öntudatos „magja”. A demokratizmus és az elitizmus egyensúlyának fenntartása máig is szempont az amerikai közéletben és alkotmányos életben. Alapelv, hogy meg kell tartani az egyensúlyt a szabadság és a rend között. Korlátot kell szabni mind az egyének, mind a kormányzat kielégíthetetlen hatalom- és birtoklásvágyának. A törvényhozás és a bíróságok feladata nem csupán az egyén természetes alapjogainak védelme, hanem a rend korlátainak védelme is. Ezért az alkotmányban a három hatalmi ág nem csupán egymástól elválasztott, hanem külön, erejüknél fogva egymást nem csupán ellenôrzô, hanem ellensúlyozó hatalmi központ is. Továbbá a szövetségi kormányzatnak az ellensúlya a tagállami hatalom. A hatalomkoncentráció 
gátja az állandó konszenzuskényszer. Az elnöknek is mindig konszenzust kell kötnie, nemcsak az ellenpárt kongresszusi tagjaival, hanem saját pártjának kétévente cserélốdố kongresszusi tagjaival is. Ahogy a Kongresszuson belül, úgy a pártok felépítésében is biztosított a különbözô érdekek és meglátások konszenzusának, szövetségének kialakítása. A választási rendszer szándékosan nem kedvez az európai típusú, állandó és jól szervezett pártstruktúrának, inkább a dinamikus, változó érdekartikulációnak. A közéletben az egyensúlyt a józan ész tudja biztosítani, és az alkotmányos életet, jogot és szokásokat, ezek érvényesülését kell szolgálnia (Hamza, 2016:5-22).

Az alkotmányt elfogadó alkotmányos érvelések célja, amely az alkotmány elfogadásához, majd a ratifikációval történố hatályosításhoz is elvezetett, egy olyan államberendezkedés létrehozása volt, amely lehetôvé teszi az eddig felmerült és a jövớben megjelenô újabb kihívások hatékony szövetségi kezelését. Ez csak akkor megvalósítható, ha biztosított a különbözó érdekek megfeleló szintú egyeztetése, és így konszenzusok, kompromisszumok keresése, megtalálása, érvényesítése. Ezért a szövetségi hatalom intézményei nem lehetnek olyan erôsek, hogy a központi források minél szélesebb elosztását valósítsák meg, mert ez kiemelhet a kormányzathoz közel álló gazdasági és más kisebbségi csoportokat, amelyek a szövetségi hatalmat felhasználva, a maguk kizárólagos elónyét biztosítanák. Ez veszélyezteti mind a személyes, mind a tagállamok szabadságát, mert az egyes lobbik egyedi érdekekért az államhatalmat felhasználva csoportosítják, koncentrálják az egyes forrásokat. Ezzel veszélyeztetik mások tulajdonát, a gazdálkodás szabadságát, de így magát a szabadságjogok hétköznapi gyakorlását is. A szabadság veszélyeztetése zsarnoki, korrupt hatalmat és hatalomgyakorlást eredményez. Ez viszont az Uniót és a tagállamok létét veszélyezteti, mert a zsarnoki hatalom jellemzôje az öncélúság, amely miatt nem lehet és nem is képes a bel-és külpolitikai realitásokat helyesen kezelni. A kevesek magánérdekét megtestesító oligarchikus hatalomgyakorlás, mint minden kormányzat legnagyobb veszélye, a korlátlan hatalomvágyat és a mások, valamint a köz érdekét nem nézó korlátlan vagyonszerzés eszközévé teszi a szabadságjogokat szükségszerúen akadályozó, sốt eltipró, magának az államnak a vesztét okozó központi hatalmat. Ugyanakkor az érdekegyeztetések rendszere, a kompromisszumok megtalálása a kisebbségi érdekek érvényesülését is lehetôvé kell hogy tegye. Nem hozható önmagában többségi döntés, azt meg kell elôznie a minél szélesebb érdekegyeztetésnek, amely a kisebbségi érdeket is védi. Ezzel együtt az sem helyes, hogy egyes kisebbségi célok megakadályozzák a nagy többség akaratának érvényesülését.

Így idôroól időre meg kell találni, és a jövôre nézve is biztosítani kell a tagállamok és a szövetségi állam közötti hatalommegosztás rendszerét. A szubszidiaritás alkotmányos elvét minden szinten, a gyakorlatban megvalósuló, tulajdonképpen az addig is múködô elvének további fenntartását kell biztosítani. Sôt, sokkal inkább külön, egymást egyensúlyban tartó központi, szövetségi hatalmakat kell létrehozni, mint a hatalommegosztás montesquieu-i elvét alkalmazni szövetségi szinten. A hatalmi egyensúly nemcsak a szövetségi állam és a tagállamok, hanem a kisebb tagállamok garanciális jogainak, az autonómiájuk védelmét is jelenti a nagyobb államokkal szemben is. 
A tagállami bíróságokkal párhuzamosan létrehozandó szövetségi bíróságoknak egyszerre kell a szövetségi rendszert védeni, és megakadályozni, hogy túlhatalom vagy kisebbségi hatalom alakuljon ki. Védeniük kell a tagállamokat a központi kormányzat alkotmányon túli beavatkozásától, valamint a polgárok jogait is az államhatalommal szemben.

Az Egyesült Államok alkotmányának folytonossága és hatályban maradása ezen elvek hatékony együttes alkalmazásának köszönhetô. A köztársaságpártiság, a szabadság, a moralitás, a magántulajdon sérthetetlensége, az igazságosság és az egyenlőség arányos és idôrôl idôre változó értelmezése, az állandó konszenzuskényszer a különbözô érdekek között képessé tette az államot, hogy a 20. századra a világtörténelem legnagyobb súlyú erejévé válhasson.

\section{FELHASZNÁLT IRODALOM}

Bacon, Francis (1995): Novum Organum I. Új Atlantisz. Nippon Kiadó, Budapest.

Egedy Gergely (2014): Konzervatív gondolkodás és politika az Egyesült Államokban. Századvég Kiadó, Budapest. Egedy Gergely (2016): Az Egyesült Államok kulturális identitása: Russell Kirk értelmezése. In: Konzervatív reneszánsz az Egyesült Államokban. Szerk. Pogrányi Lovas Miklós, Századvég Kiadó, Budapest.

Hamza Gábor (2016): Alkotmányfejlôdés az Amerikai Egyesült Államokban, különös tekintettel a hatalmi ágak megosztására. Parlamenti Szemle, 1. évf., 1. sz.

Képes György (2003): A tökéletesebb unió: az Amerikai Egyesült Államok Alkotmánya. Gondolat Kiadó, Budapest. Kirk, Russell (1990): The Conservative Constitution. Regnery Gateway, Washington.

Ostrom, Vincent (1994): The Meaning of American Federalism. Constituting a Self-Governing Society. ICS Press, San Francisco.

Semonche, John E. (2000): Keeping the Faith. A Cultural History of The U.S. Supreme Court. Rowman \& Littlefield Publishers, Boston.

Tóth Zoltán József (2017): Az Amerikai Egyesült Államok alkotmánytörténete. Jegyzet, megjelenés elôtt. 